This is an Accepted Manuscript of an article published by Taylor \& Francis Group in Journal of Environmental Science and Health, Part A on 12 Jun 2019, available online: https://doi.org/10.1080/10934529.2019.1623597

\title{
Anaerobic digestion of wastewater rich in sulfate and sulfide: Effects of metallic waste addition and micro-aeration on process performance and methane production
}

\author{
SILVIO MONTALVO ${ }^{1 *}$, CÉSAR HUILIÑIR ${ }^{1}$, RAFAEL BORJA $^{2}$, ALEJANDRA $^{*}$ \\ CASTILLO $^{1}$, and ILEANA PEREDA ${ }^{3}$
}

\footnotetext{
${ }^{1}$ Laboratorio de Biotecnología Ambiental, Departamento de Ingeniería Química, Universidad de Santiago de Chile, Santiago de Chile, Chile.

${ }^{2}$ Instituto de la Grasa (CSIC), Campus Universitario Pablo de Olavide, 41013 Sevilla, Spain.

${ }^{3}$ Universidad Tecnológica de La Habana, CP 19390, Marianao, La Habana, Cuba.
}

\begin{abstract}
This work explores the effect of two metallic wastes (mining wastes, MW; fly ashes, FA) and micro-aeration (MA) on the anaerobic digestion of wastewater which is rich in sulfate and sulfide. Two initial COD concentrations (5000 and $10000 \mathrm{mg} / \mathrm{L}$ ) were studied under both conditions in batch systems at $35{ }^{\circ} \mathrm{C}$, with a fixed $\mathrm{COD} / \mathrm{SO}_{4}{ }^{2-}$ ratio $=10$, with 100 $\mathrm{mg} / \mathrm{L}$ of $\mathrm{S}^{2-}$. It was observed that the use of MW and FA in the assays with an initial COD concentration of $10000 \mathrm{mg} / \mathrm{L}$ resulted in a simultaneous increase in COD removal, sulfate removal, sulfide removal and methane generation, while MA only improved the COD and
\end{abstract}


sulfide removals in comparison with the control system. On the contrary, the use of MW, FA or MA in systems with initial COD concentrations equal to or lower than $5000 \mathrm{mg} / \mathrm{L}$ did not show any improvement with respect to the control system in terms of COD removal, sulfate removal or methane generation, with only sulfide removal being positively affected by MW and FA.

*Address correspondence to Silvio Montalvo, Laboratorio de Biotecnología Ambiental, Departamento de Ingeniería Química, Universidad de Santiago de Chile, Ave. Lib. Bdo O’Higgins 3363, Región Metropolitana, Santiago de Chile. Phone: 56 992683378; Fax: 56 2 6811422; Email: silvio.montalvo@usach.cl

KEYWORDS: Anaerobic digestion, fly ashes, micro-aeration, mining wastes, sulfide removal.

\section{Introduction}

At present, the anaerobic digestion of industrial wastewater is a process with low operational costs, which also allows obtaining sub-products such as biogas with an important energetic value. ${ }^{[1-3]}$ Nevertheless, several of these industrial wastewaters coming from fishery, tannery, food processing, distillery, pulp and mill, mining, metallurgical, chemical, pharmaceutical, and oil refinery industries and livestock farming have compounds which are problematic for biological processes, ${ }^{[4,5]}$ such as sulfates and sulfides, ${ }^{[6]}$ which cause serious problems not only in biological processes, but also in the use of its products, namely biogas. ${ }^{[7-9]}$ Sulfates are reduced to sulfides by sulfate-reducing bacteria (SRB) that use a wide variety of organic and inorganic substrates as electron- 
acceptors such as $\mathrm{H}_{2}$, ethanol, fatty acids, etc. ${ }^{[10,11]}$ Several of these compounds are intermediates of the anaerobic process, and therefore, a competition for substrate is generated by the different anaerobic microorganisms (acidogenic, acetogenic and methanogenic biomass). From a thermodynamic and kinetic point of view, a sulfate reduction process is more favorable than methanogenesis. This fact implies that SRB can out-compete with methanogenic biomass when the ratio $\mathrm{COD} / \mathrm{SO}_{4}{ }^{2-}$ is low, a situation that decreases methane generation. ${ }^{[12]}$ Reducing $1 \mathrm{~g}$ of $\mathrm{SO}_{4}{ }^{2-}$ equals $0.67 \mathrm{~g}$ COD which means that for every $\mathrm{kg}$ of $\mathrm{SO}_{4}{ }^{2-}$ that is reduced the production of $\mathrm{CH}_{4}$ decreases in $0.23 \mathrm{~m}^{3}$. ${ }^{[13]}$ Using the COD/sulfate ratio as a reference parameter, performance losses on both $\mathrm{CH}_{4}$ production and organic matter removal should not be observed for values higher than $10 .{ }^{[14]}$ On the other hand, the product of this reaction is sulfide, a compound that generates problems not only in the biological processes (as inhibitor), but also in the combustion of biogas in engines. There is a general consensus that anaerobic inhibition begins to occur at values of 50-250 mg sulfur (from sulfide)/L that it is observed at influent sulfate concentrations higher than $2 \mathrm{~g} \mathrm{SO}_{4}{ }^{2-} / \mathrm{L} .{ }^{[15]}$ Indeed, sulfide is commonly undesired in wastewater treatment processes due to: i) potential corrosion; ii) interference with other biological/chemical processes; iii) health and safety risks to workers. Therefore, it is very important to seek other alternatives that permit a decrease in the concentration of these compounds in anaerobic processes.

Among the technologies proposed for decreasing the sulfide concentration in anaerobic reactors are the addition of $\mathrm{Fe}$ for the precipitation of it, ${ }^{[16,17]}$ aerobic biofiltration and micro-aeration for the oxidation of it to elemental sulfur or sulfate. ${ }^{[18]}$ Wastes rich in $\mathrm{Fe}$ such as waste iron powder ${ }^{[19]}$ or rusty scrap iron ${ }^{[20,21]}$ have been used for the removal of 
$\mathrm{H}_{2} \mathrm{~S}$ with good results, not only in $\mathrm{H}_{2} \mathrm{~S}$ removal, but also for improving methane generation. On the other hand, micro-aeration has been applied as a biological alternative even at full scale, with good results for sulfide removal. ${ }^{[22]}$ Until now, there has been no research work that compares these technologies in wastewater which is rich in sulfates and sulfide. A comparison is necessary, not only in terms of sulfide removal or methane generation, but it is also important to know the effects of the sulfate-reducing process.

Even though metallic wastes rich in Fe have been explored for sulfide removal, some other metallic wastes that can be used for this purpose such as mining wastes or fly ashes from thermoelectrical plants have not been proposed. Mining wastes and fly ashes can contain not only Fe for precipitation of $\mathrm{H}_{2} \mathrm{~S}$, but also other trace elements that can be useful for the stimulation of anaerobic digestion processes. ${ }^{[4,23]}$ Some experiments have been reported for the use of mining wastes ${ }^{[24,25]}$ and fly ashes ${ }^{[25-27]}$ as stimulatory elements for anaerobic digestion. However, to the best of our knowledge, no comparative study has been carried out on the effects of these wastes and micro aeration on dissolved hydrogen sulfide $\left(\mathrm{H}_{2} \mathrm{~S}\right)$ reduction in digester or anaerobic sulfate removal.

Thus, the goal of this work was to determine the effect of metallic wastes such as mining wastes and fly ashes and micro-aeration on the anaerobic digestion of wastewater which is rich in sulfates and sulfide. The effects on COD, sulfate and sulfide removals were evaluated, including their influence on methane generation.

\section{Materials and methods}

\section{Experimental setup}


The anaerobic reactors used were glass mini-vessels of $250 \mathrm{~mL}$ total volume and $200 \mathrm{~mL}$ effective volume. Each reactor was filled with $40 \mathrm{~mL}$ of inoculum and $160 \mathrm{~mL}$ of synthetic wastewater, which correspond to $20 \%$ and $80 \%$ of the effective volume, respectively. ${ }^{[28]}$ All the reactors were sealed and the headspace of each flask was flushed with nitrogen at the beginning of each assay. The produced biogas was passed through a $3 \% \mathrm{NaOH}$ solution to capture $\mathrm{CO}_{2}$, and the remaining gas was assumed to be methane. This system for measuring methane production is commonly used in this kind of experiments. ${ }^{[29]}$ Due to the importance of maintaining the homogeneity of the sludge within the reactors, they were subjected to a moderate manual stirring several times per day for several seconds. In addition, the biogas generated inside the reactors also allowed for maintaining the agitation of the reactor contents. The anaerobic digester temperature was kept at $35 \pm 2{ }^{\circ} \mathrm{C}$ using automatically controlled aquarium heaters.

\section{Characteristics of metallic wastes}

The mining wastes were obtained from an industry of Nickel mineral processing, where a solid waste known as "Cola" is produced, which was used in this work. The fly ash was obtained from a thermoelectric power plant located in the north of Chile. Ash was taken from electrostatic precipitators used to collect particulate matter generated by the combustion of bituminous coal, which is placed before the gaseous effluents that leave the plant. The main characteristics of these wastes are shown in Table 1. The particulate diameter of the residues was $1-1.4 \mathrm{~mm} .{ }^{[28]}$ 


\section{Inoculum, substrate and experimental design}

The inoculum was obtained from an anaerobic reactor located in the La Farfana Water Treatment Plant of Aguas Andinas in Santiago, Chile. It had a specific methanogenic activity of $0.32 \mathrm{~g} \mathrm{CH}_{4}-\mathrm{COD} /(\mathrm{g}$ VSS $\cdot \mathrm{d})$. The inoculum had the following characteristics: $16,696 \pm 936 \mathrm{mg} / \mathrm{L}$ volatile suspended solids (VSS); $12-15 \mathrm{mg} / \mathrm{L} \mathrm{s} \mathrm{S}^{2-} ; \mathrm{pH}=7.4$. The experimental design tested consisted of two conditions: Low and High load. The main difference between each condition was the initial soluble Chemical Oxygen Demand (COD) and sulfate concentrations. Low load had initial concentrations of soluble COD and sulfate of 5,000 and $500 \mathrm{mg} / \mathrm{L}$, respectively; high load had initial concentrations of soluble COD and sulfate of 10,000 and $1000 \mathrm{mg} / \mathrm{L}$, respectively. The $\mathrm{COD} / \mathrm{S}^{-S}{ }_{4}{ }^{2-}$ ratio of 10 was maintained in all the assays, in order to favor the methanogenesis. ${ }^{[14]}$ The rest of the compounds from synthetic wastewater were kept constant in both conditions, as is shown in Table 2.

In both conditions, all the treatments proposed were performed in triplicate: Mining wastes (MW), Fly ashes (FA) and micro-aeration (MA). Furthermore, a control assay was done for each condition, also in triplicate. The control reactors contained the same amounts of inoculum and substrate (low or high load) than those used in each experiment performed, but without addition of MW, FA or MA. The assay with MW consisted of an experiment where $131.6 \mathrm{mg} / \mathrm{L}$ of "Cola" were added $(5 \mathrm{mg} / \mathrm{L}$ of $\mathrm{Ni})$ to each reactor; in the assay with FA, $50 \mathrm{mg} / \mathrm{L}$ of fly ash coming from a thermoelectric plant were added to the reactors; finally, the assay with MA consisted of bioreactors aerated continuously with an air-flow 
rate of $0.008 \mathrm{vvm}$ (volume air/volume liquid per min) throughout the digestion period. All these conditions were selected in accordance with the literature and taking into account previous experiments. ${ }^{[25,27,30]}$ For each condition or group of experiments, 54 mini digesters (in duplicate) were used and from time to time a couple of reactors were taken from the system, and the corresponding analyses were performed, which would determine representative results for that day of digestion. In this way, each value of the analyzed samples represented a point in the evolution curves corresponding to the different physicochemical parameters evaluated. The reactors operated in batch mode until methane accumulation remained constant. Methane production was monitored daily throughout the process.

\section{Chemical and statistical analyses}

The following chemical parameters were determined: soluble chemical oxygen demand $\left(\mathrm{COD}_{\mathrm{s}}\right)$, total volatile solids (TVS), volatile suspended solids (VSS), alkalinity, sulfate, sulfide and $\mathrm{pH}$. All these parameters were analyzed according to APHA Standard Methods.

${ }^{\text {[31] }}$ All analytical determinations were made at least in duplicate with a frequency of two or three times per week, except methane volume, which was measured daily. The measurements of Total alkalinity (TA) and Bicarbonate alkalinity (BA) permitted the calculation of alkalinity ratio $\alpha$ :

$$
\alpha=\frac{\text { Bicarbonate Alkalinity }}{\text { Total Alkalinity }}
$$

Values of $\alpha$ ratio higher than 0.5 indicated a good performance and an adequate stability of the system. ${ }^{[32]}$ The determination of metal concentrations was made using a Perkin Elmer 
Optima 3000 ICP according to standard protocols based on official methods of the US-

EPA. ${ }^{[33]}$

The statistical analysis used in order to compare data between the control system and the applied treatments was the $t$-test, with a significance level $=0.05$. To determine the differences between each treatment a one-factor analysis of variance (ANOVA) was applied. All these analyses were done using the Excel 2010 toolbox.

The removal efficiencies of COD, sulfate and sulfide were determined by the following equation:

$$
\text { Efficiency }(\%)=\left(\frac{c_{\text {initial }}-c_{\text {final }}}{c_{\text {initial }}}\right) \times 100
$$

where: $c_{\text {initial }}$ is the initial concentration of each component, and $c_{\text {final }}$ is the concentration of each component at the end of the batch assay.

\section{Results and discussion}

Effect of mining wastes (MW), fly ashes (FA) and micro-aeration (MA) on COD removal and methane generation

The effect of MW, FA and MA on CODs degradation can be seen in Figure 1. For low load (Fig. 1A), the CODs removal was high and quick, obtaining up to $97 \%$ after 20 days of reaction, with no effect of the three treatments on this parameter. Even though the CODs degradation rate at the beginning of the assays appeared faster for the MA treatment, the statistical analysis ( $t$-student) showed that there were no statistically significant differences 
between the profiles. At a high load (Fig. 1B) the situation was quite different, with a clear effect of all the treatments on the CODs removal, although the kinetics appeared to be similar. The statistical analysis confirmed this situation, showing that there were statistically significant differences between the CODs profiles of the control and each treatment $(p<0.05)$. The highest CODs removal was achieved using MA $(91.5 \%)$, which was $38.4 \%$ higher than the control one $(66.1 \%)$. For MW and FA, the CODs removal was 79.8 and $85.4 \%$ higher, respectively, than for the control. This higher CODs removal using MA can be attributed to the better $\mathrm{S}^{-2}$ removal under this condition (see Fig. 3B), allowing better environmental conditions for the methanogenic archaea metabolism and sulfatereducing bacteria.

Comparing the two conditions studied (Fig. 1A and Fig. 1B), it can be clearly observed that the treatments were much more necessary and effective for high initial CODs concentrations. In higher CODs concentrations, the competition between methanogenic and sulfate -reducing bacteria was lower even though the $\mathrm{COD} / \mathrm{SO}_{4}{ }^{2-}$ was kept constant in both conditions, allowing the sulfate-reducing bacteria to generate $\mathrm{H}_{2} \mathrm{~S}$, which at high concentrations could inhibit the methanogenic microorganisms and decrease the process efficiency.

Therefore, it is necessary to find appropriate strategies to simultaneously enhance the CODs removal and methane yield, reducing $\mathrm{H}_{2} \mathrm{~S}$ production. An efficient strategy has been proposed recently by Dai et al. ${ }^{[8]}$, which consisted of pretreating the substrate (waste activated sludge) at $\mathrm{pH} 10$ for $8 \mathrm{~d}$ and adjusting the system at neutral $\mathrm{pH}$ to produce methane for $20 \mathrm{~d}$. This procedure allowed the synchronous enhancement of COD removal and methane production and reduction of $\mathrm{H}_{2} \mathrm{~S}$ production during the anaerobic digestion of 
waste activated sludge. These experimental results showed that the methane yield of sludge pretreated at $\mathrm{pH} 10$ in semi-continuous stirred anaerobic reactors for $84 \mathrm{~d}$ was $49.6 \%$ higher than that obtained in the control. Meanwhile, the production of $\mathrm{H}_{2} \mathrm{~S}$ was $54.2 \%$ lower than that detected in the control. ${ }^{[8]}$

The effect of MW, FA and MA on the accumulated methane volume production is shown in Figure 2.

It is important to note that the methane volume measurement in the assay with MA was neglected due to the air flow-rate, which could have modified the methane volume value; however, the injection of air at low flow-rate in an anaerobic bioreactor did not affect the calorific value of biogas. Indeed, Porpatham et al., ${ }^{[34]}$ demonstrated that "diluted" biogas could be used in a combustion engine, and they found that a decrease in methane concentration from $70 \%$ to $50 \%$ only reduced the spark-ignition engine's energetic performance by $0.9 \%$ for the same mass methane flow. At low load (Fig. 2A), the methane production was similar between the control system and the assays with treatment, without statistical significant differences between the treatments and the control system $(p>0.05)$. This behavior agrees with the COD removal values obtained in these assays (Fig. 1A). The methane production in all these assays was very fast, obtaining the greatest amount of methane within the first 10 days in all cases, and achieving its steady-state after 30 days. At high load (Fig. 2B), there was an effect of MW and FA on the process, a situation that was also reflected in the statistical analysis $(p<0.05)$. The systems with FA generated a slightly higher volume in comparison to the MW, both being higher than the control system; the accumulated methane volume was $41 \%$ higher than the control for the system with FA, while it was $31 \%$ higher than the control for the system with MW. This higher methane 
production also agrees with the slightly higher COD removal achieved using FA. A possible explanation for this result could be the greater trace element bio- availability in the system with FA, which is reflected in better values for $\alpha$ ratio and $\mathrm{pH}$ (Fig. 5B and 6B). Specifically, the higher contents in $\mathrm{Fe}, \mathrm{Cu}, \mathrm{Al}, \mathrm{Ba}, \mathrm{Mn}$ and $\mathrm{Zn}$ of the FA compared to the values present in MW could entail a higher stimulation of the growth and metabolism of the methanogens, causing a higher final methane production in the reactors with FA. Moreover, the higher content of Fe in FA (3083 mg/kg) compared to MW (306 mg/kg) could also explain the higher methane production found in the reactors with FA. Reported Fe advantages include: its capacity to decrease the oxidative-reductive potential (ORP) of the anaerobic media and, therefore, provide a more favorable environment for anaerobic digestion; and its role as co-factor of several key enzymatic activities, such as pyruvateferrodoxin oxidoreductase, which contain Fe-S clusters and play a key role in fermentation. ${ }^{[35]}$ On the other hand, although the sulfide concentration in the system with FA was always higher than that detected in the system with MW, the sulfide concentration values were not high enough to inhibit methane production in this case. ${ }^{[12]}$ Figure 2 also shows that the methane generation at high load was slower than in the process at low load, and showed a longer lag-phase at high load. This also shows that high load required more time for stabilization and methane generation.

Thus, it is possible to say that the three treatments studied improved the CODs removal and the methane generation at high load conditions. Initial CODs concentrations equal to or lower than $5000 \mathrm{mg} / \mathrm{L}$ did not require any treatment for improving COD removal and methane generation. 


\section{Effect of treatments on the sulfur compounds}

The effect of MW, FA and MA on the concentrations of both sulfide and sulfate are shown in Figures 3 and 4, respectively. Figure 3 shows that the sulfide was removed under both conditions, high and low load. At low load (Fig. 3A) the control system maintained the sulfide concentration at values superior to $90 \mathrm{mg} / \mathrm{L}$, while the systems with the different treatments decreased the concentrations by up to $18 \mathrm{mg} / \mathrm{L}$, with the MA the treatment being more effective in the sulfide removal. In the cases of MW and FA, the sulfide removal was probably carried out by sulfide precipitation, because the sulfate concentration was not increased in these systems (Fig. 4A). Even though the MA allowed for obtaining a lower sulfide concentration in the liquid phase, the ANOVA analysis showed that there were no significant statistical differences between the concentrations obtained by the application of MW, FA and MA $(p>0.05)$.

For the case of high load (Fig. 3B), the situation was different. In this case, the control system presented a decrease in sulfide concentration the first 12 days of digestion, increasing later to up to $90 \mathrm{mg} / \mathrm{L}$. This fact could be attributed to the $\mathrm{pH}$ (Fig. 6A), whose value (around 7.3) could shift the equilibrium toward the volatile form of sulfide $\left(\mathrm{H}_{2} \mathrm{~S}\right)$, allowing for the stripping of the $\mathrm{H}_{2} \mathrm{~S}$ (gaseous) and, therefore, decreasing its total concentration.

In presence of MW, FA and MA there was a fast reduction in sulfide concentration during the first 6 days and, then, there was a production of $\mathrm{H}_{2} \mathrm{~S}$ due to the performance and operation of the sulfate-reducing bacteria. The highest increase in sulfide production between days 5 and 25 was achieved in the system with FA, followed by the system with MW. The system with MA allowed the sulfide concentration to be kept at values lower than 
$30 \mathrm{mg} / \mathrm{L}$ in almost all the assays, with a small increase on the $18^{\text {th }}$ day. The higher sulfide production in the systems with FA and MW could be due to the stimulation of sulfatereducing bacteria by trace elements present in these wastes, which also allowed the higher activity of methanogenic archaea. ${ }^{[9,24]}$ On the other hand, the rapid sulfide reduction at the beginning of the assays with FA and MW also showed that these wastes allowed a decrease in sulfide concentration, possibly by precipitation. Finally, at the end of the assays the sulfide concentration decreased to values lower than $20 \mathrm{mg} / \mathrm{L}$ in all experiments. This last reduction of sulfide (after day 25) could be attributed to the presence of biological sulfide oxidation, which also agreed with the slight increase in sulfate concentration in these assays (Fig. 4B).

Figure 4 shows the sulfate concentration profiles under low and high load. Under low load condition (Fig. 4A), sulfate was virtually removed in the control system, while in the systems with FA and MW, sulfate removal efficiencies of between 96.7 and $88 \%$ were achieved. Under MA conditions, sulfate removal was lower and reached a final value of only $22 \%$. This low removal can be attributed to the inhibition of SRB due to the oxygen present in the medium. ${ }^{[36]}$ This previous research indicated that SRB are inhibited by the presence of electron acceptors such as oxygen, nitrate and nitrite. Among them, oxygen was the most inhibiting electron acceptor regardless of the carbon source used. This same study showed that after exposure to oxygen and when feeding acetate an inactivation time in the sulfate reduction activity was observed. Once the sulfate reduction activity was resumed, only $60 \%$ of the original activity was recovered. Although the presence of MW and FA allowed a high sulfate removal, the highest removal obtained at low load was achieved in the control system, with a $96.7 \%$ reduction; however, the simultaneous removal of sulfide 
and sulfate in the presence of MW and FA allowed not only for good performance of the process with high sulfate and COD removals, but also improved methane production.

At high load (Figure 4B), the performance in terms of sulfate removal was similar, with the lowest removal in the system with MA (76.4\%); however, at higher initial $\mathrm{SO}_{4}{ }^{2-}$ and COD concentrations, there was better sulfate removal in comparison to the system with low load, increasing the average removal by $336 \%$ with respect to that condition. This can be attributed to the higher bioavailability of substrate for sulfate-reducing bacteria, which allowed a better and more effective biodegradation of this more concentrated substrate. Piña-Salazar et al. ${ }^{[37]}$ also demonstrated that in sulfate-reducing reactors (down-flow fluidized bed) the sulfate removal efficiency increased when the $\mathrm{COD} / \mathrm{SO}_{4}{ }^{2-}$ ratio increased, achieving a maximum sulfate removal of $66.1 \%$ at a $\mathrm{COD} / \mathrm{SO}_{4}{ }^{2-}$ ratio of 2.5 . According to the results obtained in the present work, the use of metallic wastes (MW and FA) in the anaerobic digestion improves the global performance (COD removal, methane production, sulfide removal, sulfate removal) of this process, especially under conditions of high load. In the same way, the addition of sweetmeat waste as nutrient supplement in anaerobic upflow packed bed reactors treating sulfate rich wastewater resulted in a prompt reactivation of $\mathrm{SO}_{4}{ }^{2-}$ removal. ${ }^{[38]}$ This research demonstrated that $\mathrm{SO}_{4}{ }^{2-}$ removal was proportional to $\mathrm{COD} / \mathrm{SO}_{4}{ }^{2-}$ ratio up to 4 , at which a maximum sulfate removal (99\%) was achieved. ${ }^{[38]}$

\section{Effect of WM, FA and MA on $\mathrm{pH}$ and alkalinity ratio}

Alkalinity and $\mathrm{pH}$ are two important parameters in anaerobic digestion processes; therefore, it is interesting to know the effect of these three treatments on them in order to determine 
their influence on process stability. Figure 5 shows the variation of the $\alpha$ ratio with time, while Figure 6 shows the $\mathrm{pH}$ values observed as a function of time in each assay. For $\alpha$ ratio, at low load (Fig. 5A), the process was always performed under good conditions of alkalinity, with low accumulation of volatile fatty acids (VFAs) (data not shown). This behavior agrees with the high COD and sulfate removals, and also with the high methane production obtained in all these assays.

Regarding the $\alpha$ ratio under high load condition (Fig. 5B), the results showed an effect of MW, FA and MA on this ratio, because under these three treatments the $\alpha$ ratio increased with respect to its value found in the control system. Indeed, the control system obtained values of $\alpha$ ratio in the lower limit of a good and stable operation. According to the literature, ${ }^{[28]} \alpha$ ratio must be superior to 0.5 in order to ensure that the anaerobic system is not producing too many VFAs, which could stop the methane generation by acidification. Thus, the treatments studied allowed an improvement in the alkalinity ratio, decreasing the VFAs in the medium, a situation which also explains the higher methane production in these cases compared to the control. In addition, FA and MW make an important contribution to these alkalinity ratios, taking into account that they contain a suitable liming material derived primarily from $\mathrm{Cao}, \mathrm{MgO}$ and other alkaline metal oxides that react with water to generate net alkalinity. ${ }^{[28]}$ According to the statistical analysis, there was no significant differences among the $\alpha$ ratio values for the different treatments tested (ANOVA, $p>0.05$ ); however, there were statistically significant differences between the $\alpha$ ratio values obtained in the control and those found for each treatment $(t$-student, $p<0.05)$. For $\mathrm{pH}$ values, Figure 6 shows the results for all the conditions studied. At low load (Fig. 6A), the $\mathrm{pH}$ for all the assays was kept within the optimal range for methanogenesis, with 
values between 7.3 and 7.45 , without differences between the control system and the systems with MW, FA and MA. Statistical analysis confirmed this fact, showing that there were no statistically significant differences between the control $\mathrm{pH}$ value and the $\mathrm{pH}$ values in the assays with treatments. Therefore, at low load (low initial COD and sulfate concentrations), the $\mathrm{pH}$ was not affected by the addition of WM, FA or MA. For the case of high load (Fig. 6B), there was an initial small decrease in $\mathrm{pH}$ from 7.2 to around 7.0 during the first 6 days of digestion. This decrease can be attributed to a simultaneous decrease in the alkalinity $\alpha$ ratio (Fig. 5B) during this period, which affected the buffering capacity of the systems during this time interval, decreasing the $\mathrm{pH}$ values. From the $6^{\text {th }}$ day, the alkalinity $\alpha$ ratio increased again, causing a rise in $\mathrm{pH}$ up to values in the range of 7.5-7.7. Even though the values and tendency of $\mathrm{pH}$ in the control system and the systems with MW, FA and MA were similar, the statistical analysis showed that there was a statistically significant difference between the $\mathrm{pH}$ values of control system and the $\mathrm{pH}$ values of the system with MA $(p<0.05)$; the rest of the treatments (MW and FA) did not show statistically significant differences from the control system. The increase in $\mathrm{pH}$ in the systems with treatment agreed with the improvement in alkalinity ratio, COD removal and methane generation. A similar range of $\mathrm{pH}$ values (7.0-7.8) was found in the anaerobic digestion process of maize straw carried out in continuously stirred tank reactors (CSTR) at $38^{\circ} \mathrm{C}$, when a natural clay mineral mixture (containing basically $\mathrm{Fe}, \mathrm{Ni}$, Co and $\mathrm{Mn}$ ) was added to the reactors. ${ }^{[24]}$ These $\mathrm{pH}$ values guaranteed a well-balanced anaerobic digestion process operating at OLRs in the range of 0.5-2 $\mathrm{g} \mathrm{VS} /(\mathrm{L} \cdot \mathrm{d})$. 
Thus, it is shown that the use of MW, FA or MA improved the anaerobic digestion process, improving the alkalinity ratio and avoiding the acidification of the bioreactors, while maintaining the $\mathrm{pH}$ values around the optimal range for methanogenesis.

\section{Conclusions}

The use of mining wastes (MW), fly ashes (FA) or micro-aeration (MA) in the anaerobic digestion of wastewater rich in sulfate and sulfide improved the COD and sulfide removals, methane generation, alkalinity and $\mathrm{pH}$ for wastewater with high initial COD and sulfate concentrations. The use of MW and FA allowed the simultaneous increase of COD removal, sulfate removal, sulfide removal and methane generation, while MA only improved the COD and sulfide removals in comparison to the control system. Therefore, the use of metallic wastes as nutrient supplement resulted in an increase in the $\mathrm{SO}_{4}{ }^{2-}$ removal. Operational parameters such as alkalinity $\alpha$ ratio and $\mathrm{pH}$ also showed improved its values in comparison to the control system when WM, FA and MA were used. The use of WM, FA or MA in a system with initial CODs concentrations equal to or lower than $5000 \mathrm{mg} / \mathrm{L}$ with $\mathrm{COD} / \mathrm{SO}_{4}{ }^{2-}$ ratio $=10 \mathrm{did}$ not show any improvement with respect to control system in terms of COD removal, sulfate removal or methane generation. Only sulfide removal showed an improvement when WM, FA or MA were used under these conditions. In sulfate reducing reactors, the sulfate removal efficiency increased when the $\mathrm{COD} / \mathrm{SO}_{4}{ }^{2-}$ ratio augmented up to certain values.

\section{Acknowledgements}


The authors would like to acknowledge the financial support provided by Universidad de Santiago of Chile under project DICYT N 091711MM and the grant "Becas Iberoamerica. Jóvenes Profesores e Investigadores, Santander Universidades Convocatoria 2017” received by César Huiliñir Curío.

\section{References}

[1] Hagman, L.; Blumenthal, A.; Eklund, M.; Svensson, N. The role of biogas solutions in sustainable biorefineries. J. Clean Prod. 2018, 172, 3982-3989.

[2] Paolini, V.; Petracchini, F.; Segreto, M.; Tomassetti, L.; Naja, N.; Cecinato, A. Environmental impact of biogas: A short review of current knowledge. J. Environ. Sci. Health A 2018, 53, 899-906.

[3] Yeshanew, M.M.; Frunzo, L.; Luongo, V.; Pirozzi, F.; Lens, P.N.L.; Esposito, G. Startup of an anaerobic-fluidized bed reactor treating synthetic carbohydrate rich wastewater. J. Environ. Manage. 2016, 184, 456-464.

[4] Braga, A.F.M.; Zaiat, M.; Silva, G.H.R.; Fermoso, F.G. Metal fractionation in sludge from sewage UASB treatment. J. Environ. Manage. 2017, 193, 98-107.

[5] Kalat, D.G.; Yuceer, A. Anaerobic mesophilic and thermophilic treatability of vegetable oil refining wastewater. Process Saf. Environ. Protect. 2017, 109, 151-157.

[6] Guerrero, L.; Montalvo, S.; Huilinir, C.; Campos, J. L.; Barahona, A.; Borja, R. Advances in the biological removal of sulphides from aqueous phase in anaerobic processes: A review. Environ. Rev. 2016, 24, 84-100. 
[7] Arhoun, B.; Gómez-Lahoz, C.; Abdala-Diaz, T.; Rodriguez-Maroto, J.M.; GarciaHerruzo, F.; Vereda-Alonso, C. Production of biogas from co-digestion of livestock and agricultural residues: A case study. J. Environ. Sci. Health A 2017, 52, 856-861.

[8] Dai, X.H.; Hu, C.L.; Zhang, D.; Chen, Y.G. A new method for the simultaneous enhancement of methane yield and reduction of hydrogen sulfide production in the anaerobic digestion of waste activated sludge. Bioresour. Technol. 2017, 243, 914-921.

[9] Barrera, E.L.; Spanjers, H.; Dewulf, J.; Romero, O.; Rosa, E. The sulfur chain in biogas production from sulfate-rich liquid substrates: a review on dynamic modeling with vinasse as model substrate. J. Chem. Technol. Biotechnol. 2013, 88, 1405-1420.

[10] Guerrero, L.; Aguirre, J.P.; Muñoz, M.A.; Barahona, A.; Huiliñir, C.; Montalvo, S.; Borja, R. Autotrophic and heterotrophic denitrification for simultaneous removal of nitrogen, sulfur and organic matter. J. Environ. Sci. Health A, 2016, 51, 650-655.

[11] Muyzer, G.; Stams, A.J.M. The ecology and biotechnology of sulphate-reducing bacteria. Nat. Rev. Microbiol. 2008, 6, 441-454.

[12] Chen, J.L.; Ortiz, R.; Steele, T.W.J.; Stuckey, D.C. Toxicants inhibiting anaerobic digestion: A review. Biotechnol. Adv. 2014, 32, 1523-1534.

[13] Archilha, N.C.; Canto, C.S.A.; Ratusznei, S.M.; Rodrigues, J.A.D.; Zaiat, M.; Foresti, E. Effect of feeding strategy and COD/sulfate ratio on the removal of sulfate in an AnSBBR with recirculation of the liquid phase. J. Environ. Manage. 2010, 91, 17561765.

[14] Kiyuna, L.S.M.; Fuess, L.T.; Zaiat, M. Unraveling the influence of the COD/sulfate ratio on organic matter removal and methane production from the biodigestion of sugarcane vinasse. Bioresour. Technol. 2017, 232, 103-112. 
[15] Sarti, A.; Zaiat, M. Anaerobic treatment of sulfate-rich wastewater in an anaerobic sequential batch reactor (AnSBR) using butanol as the carbon source. J. Environ. Manage. 2011, 92, 1537-1541.

[16] Lin, H.J.; King, A.; Williams, N.; Hu, B. Hydrogen Sulfide Removal via Appropriate Metal Ions Dosing in Anaerobic Digestion. Environ. Prog. Sustain. Energy. 2017, 36, $1405-1416$.

[17] Choi, J.Y.; Kim, D.S.; Lim, J.Y. Fundamental features of copper ion precipitation using sulfide as a precipitant in wastewater system. J. Environ. Sci. Health A, 2006, 41, $1155-1172$.

[18] Jeniček, P.; Horejs, J.; Pokorna-Krayzelova, L.; Bindzar, J.; Bartacek, J. Simple biogas desulfurization by microaeration - Full scale experience. Anaerobe 2017, 46, 41-45.

[19] Andriamanohiarisoamanana, F.J.; Shirai, T.; Yamashiro, T.; Yasui, S.; Iwasaki, M.; Ihara, I.; Nishida, T.; Tangtaweewipat, S.; Umetsu, K. Valorizing waste iron powder in biogas production: Hydrogen sulfide control and process performances. J. Environ. Manage. 2018, 208, 134-141.

[20] Ruan, R.J.; Cao, J.S.; Zhang, Q.; Wu, Y.; Zhao, C.S.; Luo, J.Y.; Xue, Z.X. Performance evaluation of combining microaerobic desulfurization with addition of rusty scrap iron (RSI) during waste-activated sludge digestion. Desalin. Water Treat. 2017, 84, 169-179.

[21] Zhen, G.Y.; Lu, X.Q.; Li, Y.Y.; Liu, Y.; Zhao, Y.C. Influence of zero valent scrap iron (ZVSI) supply on methane production from waste activated sludge. Chem. Eng. J. 2015, 263, 461-470. 
[22] Sousa, M.R.; Oliveira, C.J.S.; Lopes, A.C.; Rodriguez, E.R.; Holanda, G.B.M.;

Landim, P.G.C.; Firmino, P.I.M.; Dos Santos, A.B. Technical, Economical, and Microbiological Aspects of the Microaerobic Process on $\mathrm{H}_{2} \mathrm{~S}$ Removal for Low Sulfate Concentration Wastewaters. Appl. Biochem. Biotechnol. 2016, 180, 1386-1400.

[23] Milán, Z.; Montalvo, S.; Ruíz-Tagle, N.; Urrutia, H.; Chamy, R.; Sánchez, E.; Borja, R. Influence of heavy metal supplementation on specific methanogenic activity and microbial communities detected in batch anaerobic digesters. J. Environ. Sci. Health A, 2010, $45,1307-1314$.

[24] González-Suárez, A.; Pereda-Reyes, I.; Pozzi, E.; da Silva, A.J.; Oliva-Merencio, D.; Zaiat, M. Effect of Natural Mineral on Methane Production and Process Stability During Semi-Continuous Mono-Digestion of Maize Straw. Appl. Biochem. Biotechnol. 2016, $178,1522-1533$.

[25] Pereda, I.; Irusta, R.; Montalvo, S.; del Valle, J.L. Solid mining residues from Ni extraction applied as nutrients supplier to anaerobic process: optimal dose approach through Taguchi's methodology. Water Sci. Technol. 2006, 54, 209-219.

[26] He, P.J.; Pu, H.X.; Shao, L.M.; Zhang, H. Impact of co-landfill proportion of bottom ash and municipal solid waste composition on the leachate characteristics during the acidogenesis phase. Waste Manage. 2017, 69, 232-241.

[27] Huilinir, C.; Pinto-Villegas, P.; Castillo, A.; Montalvo, S.; Guerrero, L. Biochemical methane potential from sewage sludge: Effect of an aerobic pretreatment and fly ash addition as source of trace elements. Waste Manage. 2017, 64, 140-148. 
[28] Montalvo, S.; Cahn, I.; Borja, R.; Huilinir, C.; Guerrero, L. Use of solid residue from thermal power plant (fly ash) for enhancing sewage sludge anaerobic digestion: Influence of fly ash particle size. Bioresour. Technol. 2017, 244, 416-422.

[29] Yang, H.N.; Deng, L.W.; Liu, G.J.; Yang, D.; Liu, Y.; Chen, Z.A. A model for methane production in anaerobic digestion of swine wastewater. Water Res. 2016, 102, 464-474.

[30] Montalvo, S.; Huiliñir, C.; Ojeda, F.; Castillo, A.; Lillo, L.; Guerrero, L. Microaerobic pretreatment of sewage sludge: Effect of air flow rate, pretreatment time and temperature on the aerobic process and methane generation. Int. Biodeterior. Biodegrad. 2016, $110,1-7$.

[31] APHA, AWWA, WPCF. Standard Methods for the Examination of Water and Wastewater. APHA Washington, D.C. 2012, 22th ed.

[32] Montalvo, S.; San Martin, J.; Huilinir, C.; Guerrero, L.; Borja, R. Assessment of a UASB reactor with high ammonia concentrations: Effect of zeolite addition on process performance. Process Biochem. 2014, 49, 2220-2227.

[33] Cortés, I.; Montalvo, S. Evaluation of potential methane generation in the investigation of an abandoned contaminated landfill in Santiago, Chile. Braz. J. Chem. Eng. 2016, 33, 723-731.

[34] Porpatham, E.; Ramesh, A.; Nagalingam, B. Investigation on the effect of concentration of methane in biogas when used as a fuel for a spark ignition engine. Fuel 2008, $87,1651-1659$. 
[35] Choong, Y.Y.; Norli, I.; Abdullah, A.Z.; Yhaya, M.F. Impacts of trace element supplementation on the performance of anaerobic digestion process: A critical review. Bioresour. Technol. 2016, 209, 369-379.

[36] Rubio-Rincón, F.; Lopez-Vazquez, C.; Welles, L.; van den Brand, T.; Abbas, B.; van Loosdrecht, M.; Brdjanovic, D. Effects of electron acceptors on sulphate reduction activity in activated sludge processes. Appl. Microbiol. Biotechnol. 2017, 101, 62296240.

[37] Piña-Salazar, E.Z.; Cervantes, F.J.; Meraz, M.; Celis, L.B. Biofilm development during the start-up of a sulfate-reducing down-flow fluidized bed reactor at different $\mathrm{COD} / \mathrm{SO}_{4}{ }^{2-}$ ratios and HRT. Water Sci. Technol. 2011, 64, 910-916.

[38] Das, B.K.; Roy, S.; Dev, S.; Das, S.; Bhattacharya, J. Improvement of the degradation of sulfate-rich wastewater using sweetmeat waste (SMW) as nutrient supplement. J. Hazard. Mater. 2015, 300, 796-807. 


\section{FIGURE CAPTIONS}

Figure 1: Effect of WM, FA and MA on CODs concentration. A) Low load; B) High load. Figure 2: Accumulated methane volume for the different conditions studied. A) Low load;

B) High load.

Figure 3: Sulfide concentrations for the different conditions studied. A) Low load; B) High load.

Figure 4: Sulfate concentrations for the different conditions studied. A) Low load; B) High load.

Figure 5: Alkalinity ratio $(\alpha)$ for the different conditions studied. A) Low load; B) High load.

Figure 6: $\mathrm{pH}$ profiles for the different conditions studied. A) Low load; B) High load. 

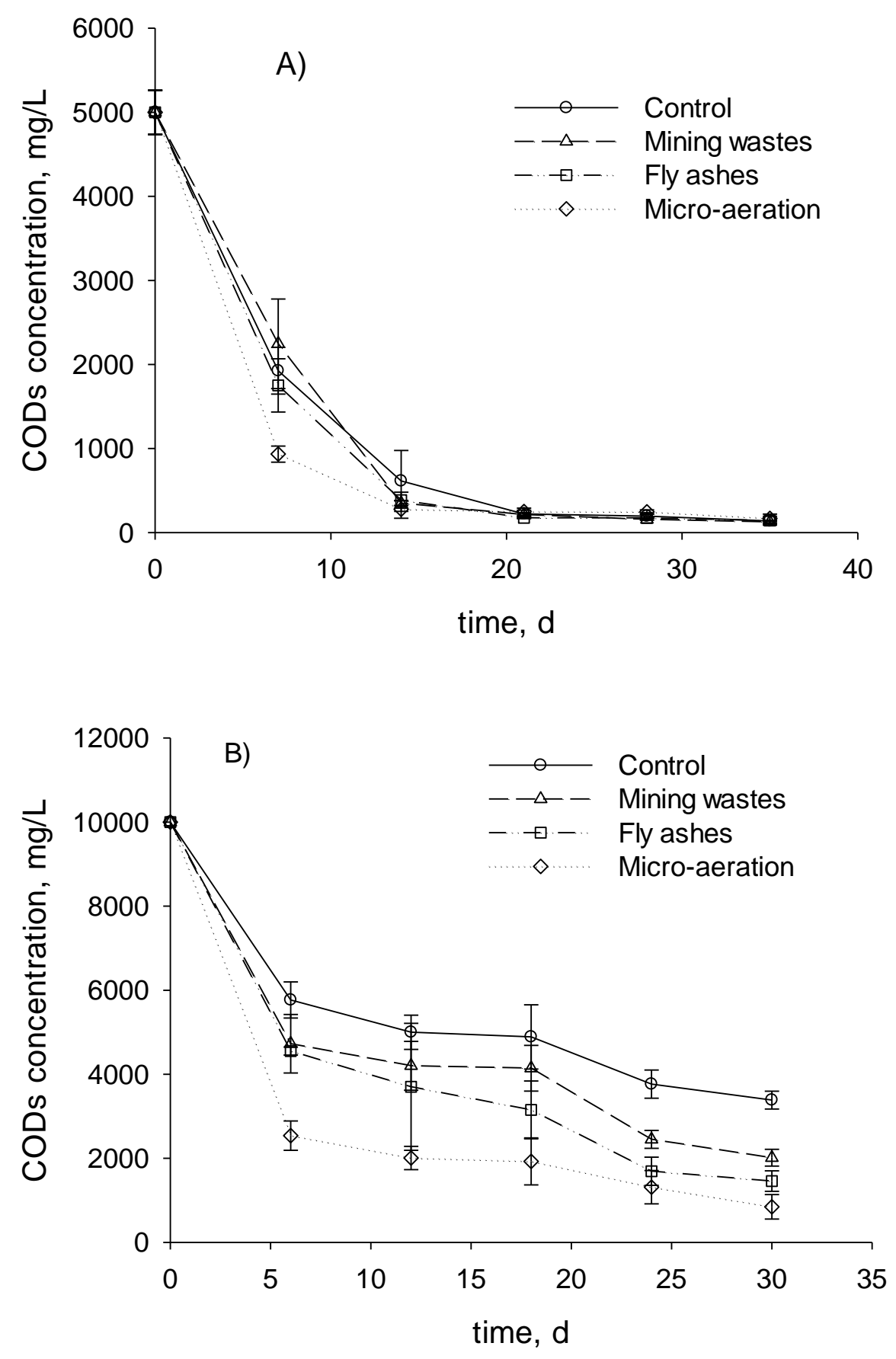

Fig. 1 

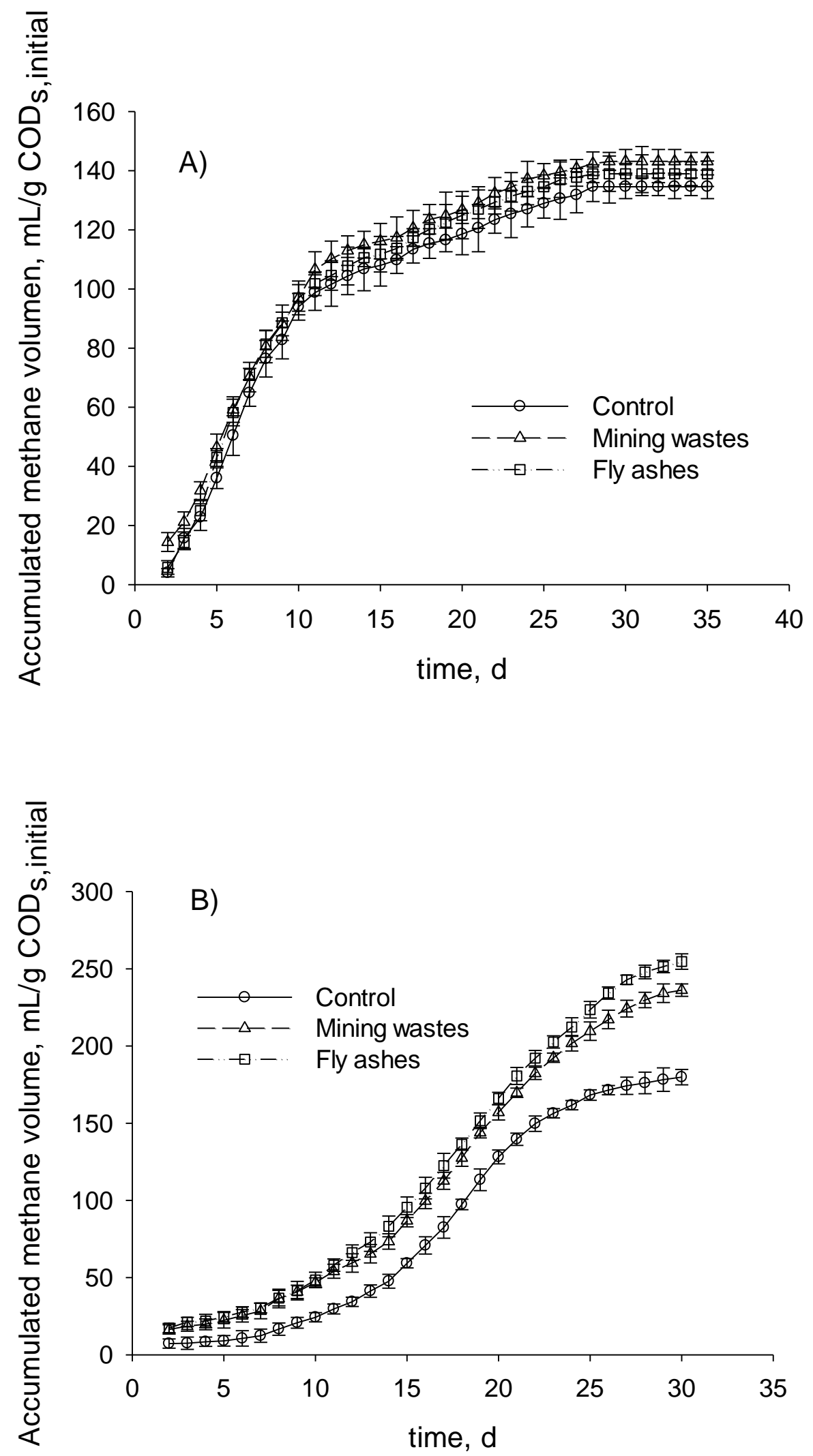

Fig. 2 

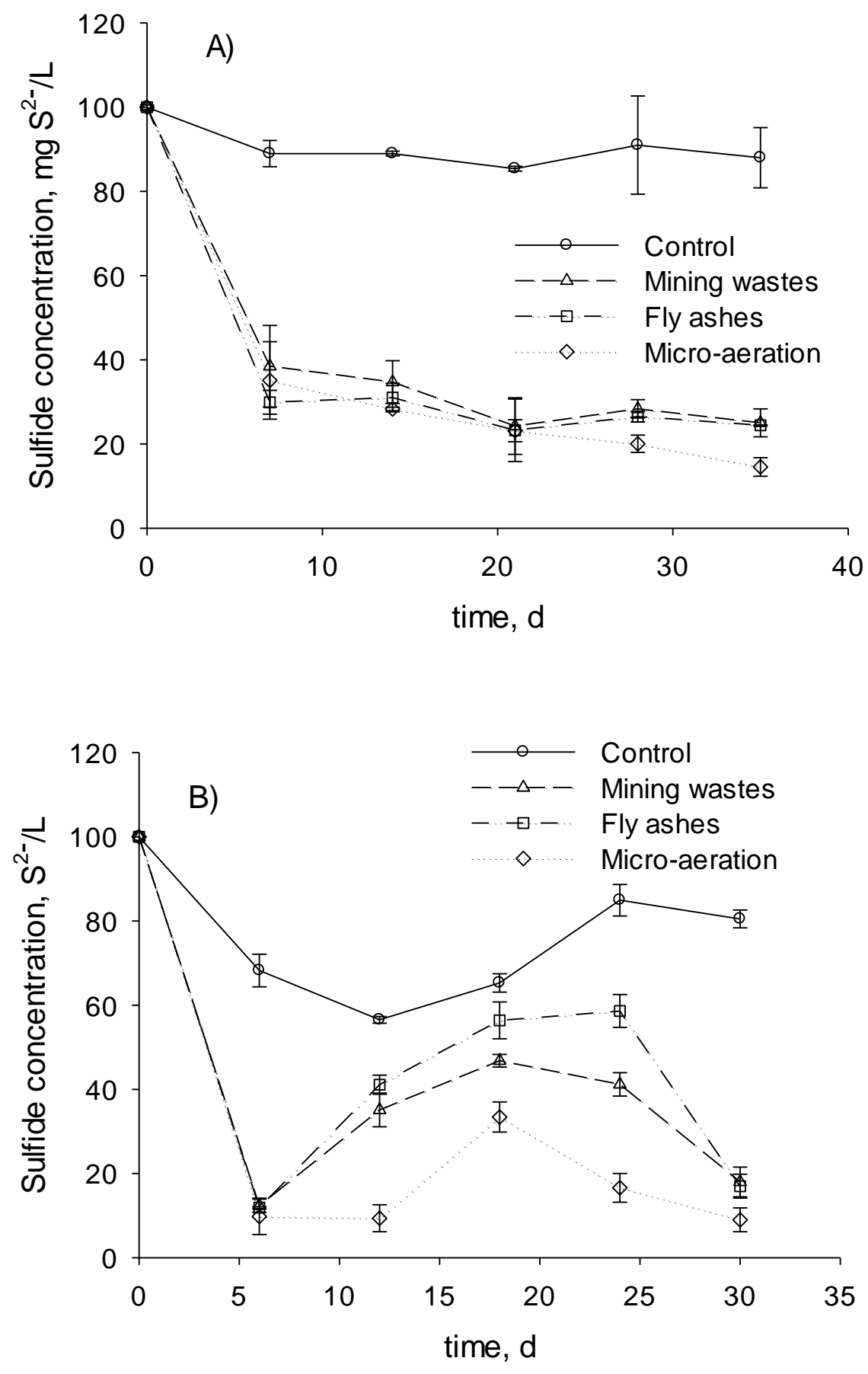

Fig. 3 

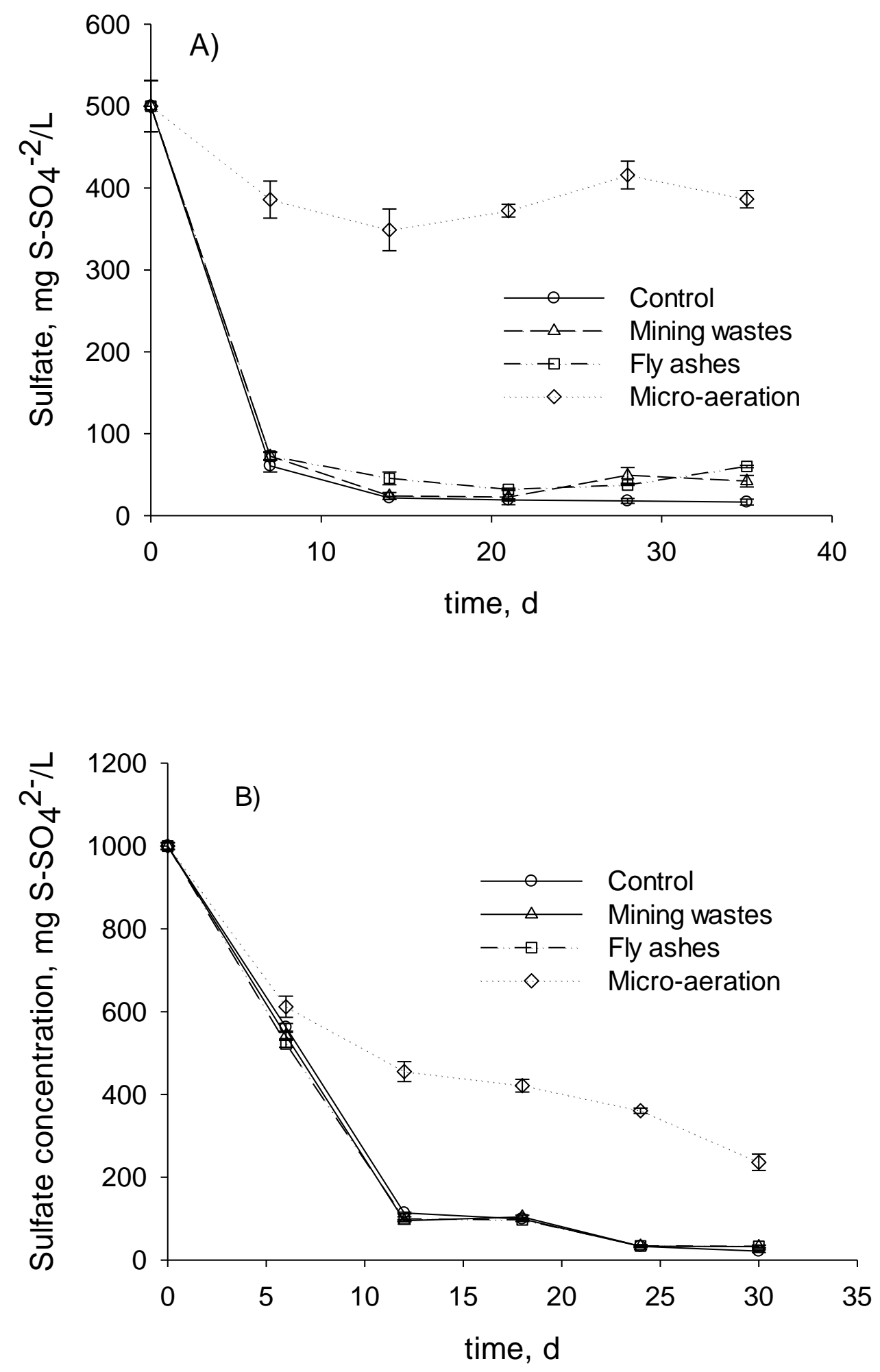

Fig. 4 

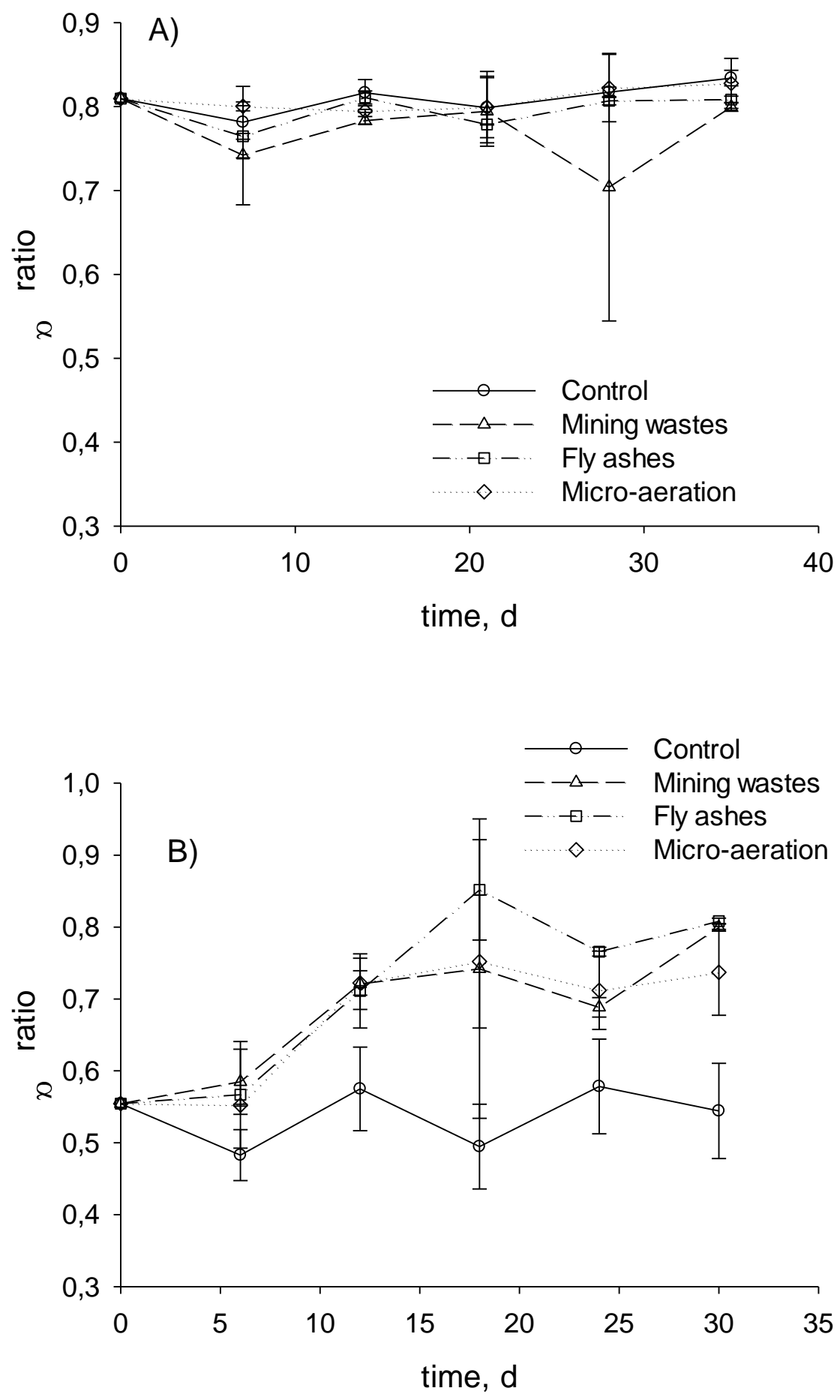

Fig. 5 

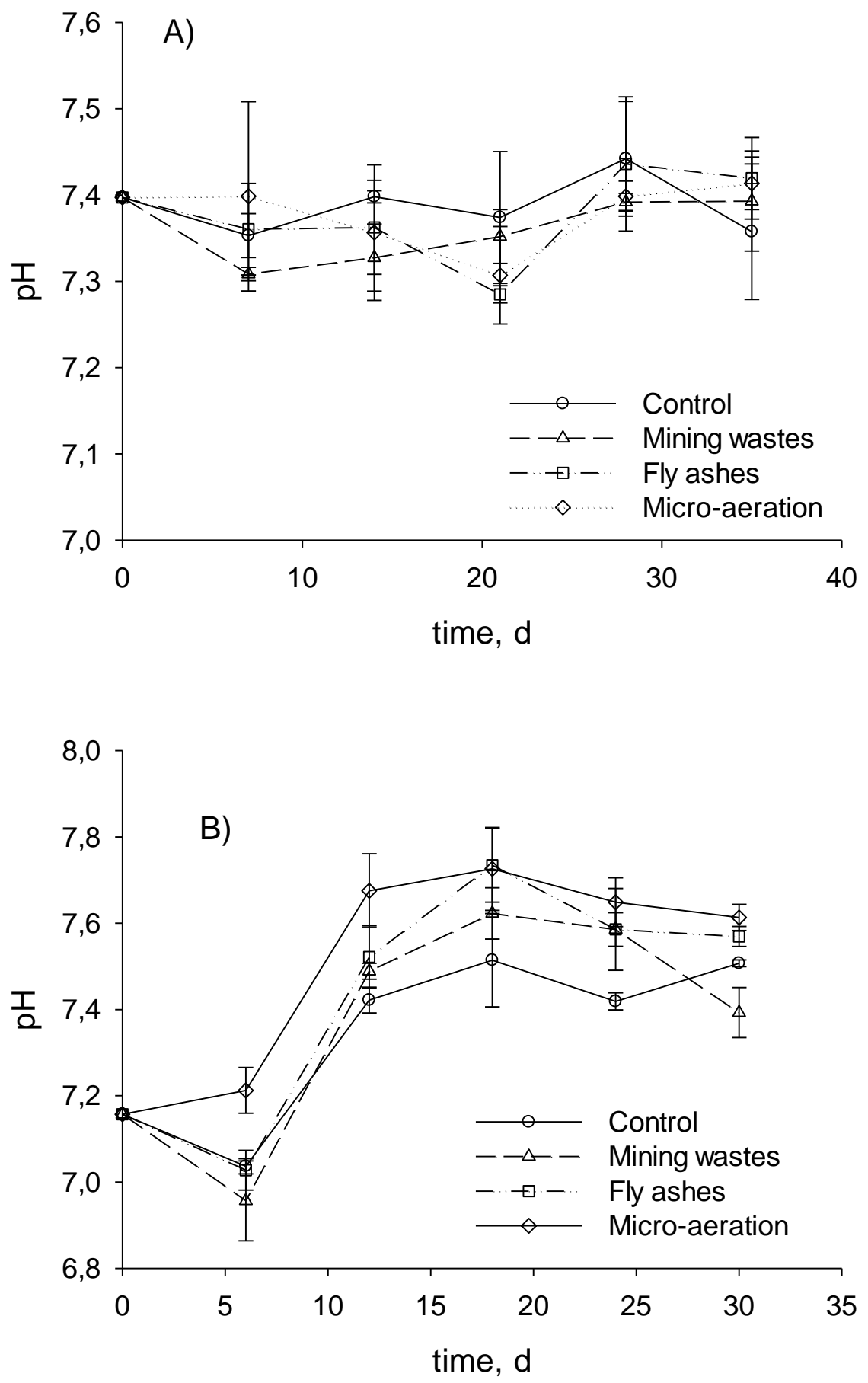

Fig. 6 
Table 1. Chemical characterization of the mining wastes and fly ash used in the experiments, $\mathrm{mg} / \mathrm{kg}$.

\begin{tabular}{ccc}
\hline Element & Mining Wastes & Fly ashes \\
\hline $\mathrm{Mg}$ & 67.32 & $<\mathrm{DL}$ \\
$\mathrm{Cr}$ & 8.24 & 2.92 \\
$\mathrm{Cd}$ & 0.02 & $<\mathrm{DL}$ \\
$\mathrm{Fe}$ & 306.61 & 3083.58 \\
$\mathrm{Ni}$ & 12.44 & 6.17 \\
$\mathrm{Cu}$ & 0.12 & 2.21 \\
$\mathrm{Co}$ & 1.63 & $<\mathrm{DL}$ \\
$\mathrm{Al}$ & 0.03 & 1315.42 \\
$\mathrm{~V}$ & $<\mathrm{DL}$ & 13.36 \\
$\mathrm{Ba}$ & $<\mathrm{DL}$ & 44.36 \\
$\mathrm{~B}$ & $<\mathrm{DL}$ & 35.03 \\
$\mathrm{Mn}$ & 0.02 & 21.05 \\
$\mathrm{Zn}$ & 0.73 & 5.4 \\
\hline
\end{tabular}

DL: Detection limit 
Table 2: Substrate concentrations used for the conditions "low load" and "high load".

\begin{tabular}{ccc}
\hline Component & Concentration Low Load, mg/L & Concentration High Load, mg/L \\
\hline $\mathrm{SO}_{4}^{-2}-\mathrm{S}$ & 519 & 1,135 \\
$\mathrm{~S}^{-2}-\mathrm{S}$ & 123 & 125 \\
$\mathrm{~N}$ & 23 & 187 \\
$\mathrm{P}$ & 4.6 & 37 \\
$\mathrm{Glucose}$ & 5,378 & 11,203 \\
$\mathrm{CODs}$ & 5,754 & 10,988 \\
$\left(\mathrm{NH}_{4}\right)_{2} \mathrm{SO}_{4}$ & 86.1 & 972.9 \\
$\mathrm{H}_{3} \mathrm{PO}_{4}$ & 11.6 & 130.5 \\
$\mathrm{Na}_{2} \mathrm{~S}$ & 299.4 & 304.3 \\
$\mathrm{NaHCO}_{3}$ & 6.25 & 6.25 \\
\hline
\end{tabular}

